\title{
Standards of the Instructional Performances in Higher-education Institutions; Conformity to Quality Requirements : Ar-Rass College of Science and Arts - Model
}

\author{
Jobier Suliman Alharbi \\ Faculty of Education, Qassim University, Saudi Arabia
}

Copyright (C) 2015 by authors, all rights reserved. Authors agree that this article remains permanently open access under the terms of the Creative Commons Attribution License 4.0 International License

\begin{abstract}
The paper studies the standard of the educational process in higher institutions and the extent of compliance with quality requirements. The college of science and Arts, Qassim University is considered as a case study. In order to assure the success of the study there are a questionnaire is designed and prepared for this purpose. It contains main eight factors, and 40 paragraphs, focusing on the choice of the accepted student, faculty member, and infrastructure at the university, students' social club, training programs for the students, evaluations of the faculty members, scientific committee, library and the university books. The questionnaire has been given to the student and the faculty members due to the fact that the study should be evaluated according to their point of view. To obtain the results and recommendations for the study, the questionnaire is analyzed statistically. The results indicate there are some defects in the main factors which considered for the study. There are 60 random samples which are considered for the study, including all departments half of them are faculty members and the other half are the students. There are just 50 questionnaire is considered after the student and faculty members fill it. The samples used are small due to ensure that those full it are aware of the topic and familiar with details of the questionnaire.
\end{abstract}

Keywords Standard, Evaluation, Accreditation, Quality Assurance

\section{Introduction}

The higher education means that different things to different people. It is well know that the graduate student from higher education institutes occupy the jobs in different fields, some in governments sectors and the other in private sector. So that it is very important to assure that they are capable to carry out their duties in their jobs. For this purpose, the Quality assurance and academic accreditation became the main goal for all universities around the world. So that the universities in Saudi Arabia established an individual units called Deanship of Quality and academic development. There are predominant concepts of higher education[1-2]:

1. It is the production of qualified human resources.

2. Training for a research career.

3. It has an efficient management for teaching provision.

4. It extends life chances. All these four concepts are not exclusive, rather they are integrated and provide the image in what higher in higher education[3].

The concept of quality, as agreed upon at the UNESCO Education conference which held in Paris, 1998 that it has multi directions must include the whole education careers and activities such as Curriculum, educational programs, scientific research, students, infra-structure, serving community, self-internal education, and determine a comparative well known standard international quality. The Quality is considered the most important tool for development and improving the education.

The Total Quality Management (TQM) receives intentions from the researchers, leaders, directors and academic people[4]. The TQM is one of the management concepts which applied currently and desired, due to the fact that it leads to the total characteristics needed for a perfect service[5]. Most of studies assured that application of the total quality management have a positive response to the performance of the Institutions, through increasing the rate of production, improving rate of profit, decreasing the costs, and enhance the employers performance[6]. The TQM is described as the third revolutionary wave after the industrial revolutions and computers revolutions. It appears due to the Intense competition between the Japanese production 
Institutions from one side with American and European institutions from other side to get consumer satisfaction[7-8].

In the higher education field the concepts of Quality is not considered till that concept evaluate significant success in the field of industrial, commerce, and technologies in the advanced countries. Till 1993, in the United States there are 220 colleges and university only considered the concepts of quality to graduate a significant candidate to fulfill the requirements in the world market[9-10].

Nowadays the concepts of total quality management receive much attention from the whole universities and higher education institutions, due to the fact that they look for academic accreditations[9]. Also it provides a competition acquiring the student adding to the people from outside the universities such as government, business companies, and all those looking for candidates for employments. Higher education and quality in the context of higher education is challenging in that definitions of higher education and quality differ widely and are often contextually influenced[11]. Different definitions of quality have been proposed based on the required purpose. This study focus on the quality assurance in higher education institutions, which have been applied firstly in the United States of America by Holms[12]. The importance of TQM in higher education institutions to expect a significance development if it is applied, subsequently the output of the higher education institution will be developed. This paper studies the standard of education in Saudi universities and how it is convenient to the requirements for quality assurance. To develop the goal a questionnaire is designed from 8 main parts each part consists of 5 factors. There are 60 questionnaire has given to both student and faculty members to define the standard of higher education and it's convenience to the requirements of quality assurance in higher education institutions.

\section{Standards}

"Standard" has come to be a vogue word in the field of quality assurance and accreditation. Sometimes, the word is used interchangeably with "criterion". Standards are statements regarding an expected level of requirements and conditions in the backdrop of which quality is assessed or that must be attained by higher education institutions and their programmes in order for them to be accredited or certified. The term "standard" itself denotes both a fixed criterion (against which an outcome can be matched) and a level of attainment. Standards vary so much in form. They may take a quantitative form, being mostly the results of benchmarking, or they may be qualitative, indicating only specific targets (e.g. educational effectiveness, sustainability, core commitments, etc.). When quantitative, standards include threshold levels that have to be met in order for higher education institutions or programmes to be accredited. More often than not, the thresholds or the "basic standards" are defined at the level of minimally acceptable quality. On other occasions, the standards refer to the highest level of quality, thus being considered as "standards of excellence". These may result from a benchmarking exercise or be asserted implicitly, being so recognized by the peers in a collegiate way. Standards may have different reference points: (i) inputs (e.g. content standards); (ii) outputs (e.g. performance standards), and (iii) processes. One may assume that standards can be general (for a degree level, e.g. a Bachelor's or a Master's Degree) or subject-specific (e.g. discipline benchmarking statements in the United Kingdom). Standards may also vary by different types of standard setting methods (such as criterion-referenced, minimal competency, or objective setting methods). In order to judge properly whether or not a particular standard of quality is met, it has to be formulated clearly and explicitly and related to specific criteria which can be further divided into (more operational) indicators.

Standards are thus related to a specific (institutional programme) culture of evidence. In the context of the growing diversity of higher education, the translation of academic quality into standards and indicators has become complex. Often, a more dynamic approach to defining and assessing standards is visible (a mixture of reality-based components and potentiality-focused ones). The challenge is threefold: (i) to diminish the number of reference standards; (ii) to relate them to appropriate performance indicators while also making use of specific criteria within a consistent culture of evidence; and (iii) to provide for sufficient flexibility in the formulation of standards in order to allow for innovative academic developments.

Standards are often used synonymously with criteria, as in the United States, while in Europe, standards are becoming increasingly distinct from criteria. A distinction between quality and standards (similar to the difference between process and outcomes) is also made. In higher education, standards are frequently set and assessed in four main areas:

- Academic standards(related to the intellectual abilities of students).

- Standards of competence(related to the technical abilities of students).

- Service standards(referring to the standards of service provided by the organization to the students)

- Organizational standards(principles and procedures by which the institution assures that it provides an appropriate learning and research environment).

Content Standards: Level of core competencies, relevant knowledge, and skills within a subject area, i.e. everything a student should know and be able to do. Content standards shape what goes into the curriculum and refers to required inputs.

Educational Standards: Level of requirements and conditions regarding different stages of the educational process and the relationship between those stages, such as inputs, processes, and outputs. Various types of educational standards exist with regard to learning resources, programmes, and results. 
Performance Standards: Levels of achievement that are deemed exemplary or appropriate, i.e. specifications of the required level of quality of a student's work to fulfill the content standards. Performance standards shape expectations for educational outcomes.

European standards:- for internal quality assurance within higher education institutions: Policies and procedures for quality assurance; approval, monitoring and periodic review of programmes and awards; assessment of students; quality assurance of teaching staff; learning resources and student support; information system; public information (as identified by ENQA)

1) for external quality assurance of higher education: Use of internal quality assurance procedures; the development of external quality assurance processes; criteria for decision; processes fit for purpose; reporting; follow-up procedures; periodic reviews; system wide analysis (as identified by ENQA)

2) for external quality assurance agencies: Use of external quality assurance procedures for higher education Official status; activities; resources; mission statement; independence; external quality assurance criteria and processes used by agencies (as identified by ENQA).

\section{Concepts of Quality: (Why this word??) (What about "academic quality"?)}

A lot of people nowadays come to discuss quality everywhere. Even non-specialists have come to deal with this area abreast. Quality in the higher education institutions consists of multidimensional, multilevel, and dynamic concepts based on the institution mission and objectives, as well as a specific standard. Its meanings depend on (i) understanding of various interests of different constituencies or stakeholders in higher education (e.g. students; universities; disciplines; the labor market; society; government); (ii) its references: inputs, processes, outputs, missions, objectives, etc.; (iii) attributes or characteristics of the academic world worth evaluating; and (iv) the historical period in the development of higher education.

A wide spectrum of definitions for "academic quality" in higher education institutes has been given which can be summarized as follows[13-14] .

- Quality as excellence: a traditional, pioneering academic view, related to the best standards of excellence (meaning high level of difficulty and complexity of the program, the seriousness of the student exams, etc.)

- Quality as fitness for purpose: a concept that makes a compromise between the need and accepted standards, based on the definition of accreditation or quality assurance. Sometimes quality in this sense is also labeled as:

(i) a value for money approach (ii) the value-added approach.
- Quality as fitness of purpose: a concept that focuses on the defined objectives and mission of the institution or programme without check of the fitness of the processes themselves in regard to any external objectives or expectations.

- Quality as enhancement or improvement: focusing on the continuous search for permanent improvement, stressing the responsibility of the higher education institutions to make the best use of its institutional autonomy and freedom. Achieving quality is central to the academic ethos and to the idea that academics themselves know best what quality is.

Quality Assurance: An all-embracing term referring to an ongoing, continuous process of evaluating the quality of a higher education system, institutions, or programmes.

Quality Control: The process of quality evaluation that focuses on the internal measurement of the quality of an institution or a programme. It refers to a set of operational activities and techniques.

Quality Management: An aggregate of measures taken regularly at system or institutional level in order to assure the quality of higher education with an emphasis on improving quality as a whole.

Total Quality Management (TQM): A particularly influential comprehensive approach to quality management that places emphasis on factors such as continuous improvement, customer focus, strategic management, need for explicit systems to assure quality of higher education, and a view of leadership and supervision that stresses employee empowerment and delegation.

Quality Audit: The process of quality assessment by which an external body ensures that (i) the institution of programme quality assurance procedures or (ii) that the overall (internal and external) quality assurance procedures of the system are adequate and are actually being carried out.

Quality Culture: It refers to a set of shared, accepted, and integrated patterns of quality (often called principles of quality) to be found in the organizational cultures and the management systems of institutions.

Quality Planning: It consists of the set of actions that establishes the objectives and the conditions referring to the quality of higher education and to the application of the mechanism of the quality system.

\section{Concepts of Accreditation}

Following in the same vein of quality assurance, accreditation has come under the zoom of scrutiny and investigation. It refers to the process by which an independent authority or private body evaluates the quality of a higher education institution as a general or specific educational programme to formally recognize if it has met certain pre-determined minimal criteria or standards[ $[13,15]$.

The accreditation process generally involves three specific steps:

i. a self-evaluation process conducted by the faculty, the administrators, and the staff of the institution or 
academic programme, resulting in a report that takes as its reference the set of standards and criteria of the accrediting body.

ii. a study visit, conducted by a team of peers, selected by the accrediting organization, which reviews the evidence, visits the premises, and interviews the academic and administrative staff, resulting in an assessment report, including a recommendation to the commission of the accrediting body

iii. an examination by the commission of the evidence and recommendation on the basis of the given set of criteria concerning quality and resulting in a final judgment and the communication of the formal decision to the institution and other constituencies, if appropriate.

Institutional Accreditation: The terms refer to the accreditation of an entire institution, including all its programmes, sites, and methods of delivery, without any implication to the quality of the study programmes of the institution.

Regional Accreditation (USA): Accreditation granted to a higher education institution by a recognized accrediting association or commission that conducts accreditation procedures in a particular geographic area (usually that of three or more states). The United States has six regional accrediting commissions.

Specialized Accreditation: The accreditation of individual units or programmes (e.g. professional education), by "specialized" or "programme" accrediting bodies applying specific standards for curriculum and course content.

Duration of Accreditation: Accreditation decisions are limited by time. The duration of validity of the accreditation license is established by the accrediting body, which generally holds the right to suspend or to renew the license, upon the satisfactory resolution of any identified issues.

Accreditation of Prior Learning: The process by which individuals are awarded credit toward qualifications based on their prior learning and (sometimes) experience (also called experiential learning). The credit is awarded upon clear evidence that the respective learning has resulted in the student having achieved the appropriate learning outcomes.

Accreditation Status: The formal recognition benefiting an institution or specialized programme for fulfilling the appropriate standards of educational quality established by the accrediting body at a regional, national, or specialized level.

Accreditation Survey: The evaluation of an institution to identify its level of compliance with the applicable standards of the accreditation body and to make determinations concerning its accreditation status. The survey includes an evaluation of documents and information (evidence) provided by the personnel of the higher education institution, following on-site observations by mandated visitors.

Portfolio for Accreditation: An accumulation of evidence (record of achievement) about specific proficiencies and the characteristics of an institution in relation to a specific type of activity, especially to learning standards. This operation can be performed either by the concerned institution or by an external assessor.

Accreditation Body: A (non-)governmental or private educational association of national or regional scope that develops evaluation standards and criteria and conducts peer evaluations and expert visits to assess whether or not those criteria are met. It is entitled to accord formal status and sometimes a license to operate to individual higher education institutions or programmes, following the successful examination of the application and evaluation of the respective educational unit. There are different types of accreditation bodies (e.g. agencies, councils, commissions, etc.), focusing on various types of accreditation; general, specialized, professional, regional, national, distance education, etc. In addition, one of the OECDUNESCO recommendations requests agencies to sustain and strengthen the existing regional and international networks.

\section{The Study Questions}

1. Is the acceptance process for the student at the university level adequate?

2. Are the faculty members qualified for educational process?

3. Is the infra structural at the university suitable for the educational process?

4. Is the libraries at each college includes the whole books that student need?

5. Are there clubs for student to practice their social activities?

6. Are there any training programmes for the student?

7. Is the evaluation process for the faculty members adequate?

8. Are the Scientific committees at the university qualifying for their duties?

\section{Goal of the Study}

The study deals with the standard of the educational process at the higher education institutions and how it is convenient for the quality assurance which leads to accreditation at the higher education institutions at Saudi Arabia (Ar-Rass college of science and Arts, Qassim University model). The study aims to determine the gap between the standard of the educational process and quality assurance.

\section{Importance of the Study}

The study is applied in order to determine exactly the gap between the standards of the educational process at the higher education institutions and requirements for the quality assurance and academic accreditations. From the analysis of 
the questionnaire the reasons makes inconvenient between standards of the educational process and the requirements for quality assurance and academic accreditations.

\section{Analysis of the Study}

The questionnaire has been designed based on the important factors affecting on the educational process. There are 75 questionnaire has been given to the student and the faculty members in all department to ensure homogeneity in the results. Table 1 Through 8 depicts the results derived from the questionnaires. The results indicate there are some advantages and some disadvantages which can be summarized as follows:

\subsection{Advantages}

1. The acceptance of the student is developed based on an equality without any kind of discrimination.

2. The accepted student is based on the community needed.

3. The student levels are convenient to the colleges.

4. The Faculty members have a very good experience in their fields, and selected based on the world standards.

5. The private laboratories are available for all colleges.

6. The students and the faculty members can borrow any number of books they need.

7. The university encourages the student to be talent through their clubs.

8. There are general lectures given to the student regularly.

9. The university evaluates the faculty members regularly and ensures the communication between them and the student.

10. The scientific committee is sufficient to cover the whole university activities.

\subsection{Disadvantages}

1. The number of student is more the ability of the college.

2. The number of classes and lectures hall is insufficient.

3. The computer laboratories can't cover the needed of the whole student.

4. The skills of some faculty members are not adequate for the educational process.

5. The numbers of books are not sufficient, and their types are also insufficient.

6. The student social clubs are not active enough to develop the student skills.

7. There are no training programmes for the students.

8. The evaluation of the faculty members is not good enough to determine their abilities.
Table 1. First Paragraph: Selecting University Students

\begin{tabular}{|c|c|c|c|c|c|}
\hline & $\begin{array}{c}\text { Strongly } \\
\text { agree }\end{array}$ & Agree & Neutral & disagree & $\begin{array}{c}\text { Totally } \\
\text { disagree }\end{array}$ \\
\hline 1 & $78 \%$ & $12 \%$ & $2 \%$ & $4 \%$ & $4 \%$ \\
\hline 2 & $44 \%$ & $12 \%$ & $8 \%$ & $32 \%$ & $4 \%$ \\
\hline 3 & $32 \%$ & $4 \%$ & $4 \%$ & $44 \%$ & $16 \%$ \\
\hline 4 & $84 \%$ & $4 \%$ & $6 \%$ & $2 \%$ & $4 \%$ \\
\hline 5 & $48 \%$ & $16 \%$ & $4 \%$ & $26 \%$ & $6 \%$ \\
\hline
\end{tabular}

Table 2. Second Paragraph, Staff Members

\begin{tabular}{|c|c|c|c|c|c|}
\hline & $\begin{array}{c}\text { Strongly } \\
\text { agree }\end{array}$ & Agree & Neutral & disagree & $\begin{array}{c}\text { Totally } \\
\text { disagree }\end{array}$ \\
\hline 1 & $40 \%$ & $14 \%$ & $10 \%$ & $28 \%$ & $8 \%$ \\
\hline 2 & $32 \%$ & $26 \%$ & $12 \%$ & $16 \%$ & $4 \%$ \\
\hline 3 & $42 \%$ & $12 \%$ & $18 \%$ & $16 \%$ & $12 \%$ \\
\hline 4 & $62 \%$ & $28 \%$ & $2 \%$ & $6 \%$ & $4 \%$ \\
\hline 5 & $58 \%$ & $16 \%$ & $10 \%$ & $6 \%$ & $10 \%$ \\
\hline
\end{tabular}

Table 3. Third Paragraph: University Infrastructure

\begin{tabular}{|c|c|c|c|c|c|}
\hline & $\begin{array}{c}\text { Strongly } \\
\text { agree }\end{array}$ & Agree & Neutral & disagree & $\begin{array}{c}\text { Totally } \\
\text { disagree }\end{array}$ \\
\hline 1 & $32 \%$ & $16 \%$ & $8 \%$ & $36 \%$ & $8 \%$ \\
\hline 2 & $46 \%$ & $12 \%$ & $6 \%$ & $28 \%$ & $8 \%$ \\
\hline 3 & $56 \%$ & $16 \%$ & $12 \%$ & $10 \%$ & $6 \%$ \\
\hline 4 & $12 \%$ & $6 \%$ & $8 \%$ & $56 \%$ & $18 \%$ \\
\hline 5 & $66 \%$ & $16 \%$ & $4 \%$ & $8 \%$ & $6 \%$ \\
\hline
\end{tabular}

Table 4. Fourth Paragraph: Library and Textbooks

\begin{tabular}{|c|c|c|c|c|c|}
\hline & $\begin{array}{c}\text { Strongly } \\
\text { agree }\end{array}$ & Agree & Neutral & disagree & $\begin{array}{c}\text { Totally } \\
\text { disagree }\end{array}$ \\
\hline 1 & $30 \%$ & $16 \%$ & $8 \%$ & $8 \%$ & $38 \%$ \\
\hline 2 & $18 \%$ & $12 \%$ & $6 \%$ & $56 \%$ & $8 \%$ \\
\hline 3 & $32 \%$ & $10 \%$ & $8 \%$ & $38 \%$ & $12 \%$ \\
\hline 4 & $52 \%$ & $14 \%$ & $14 \%$ & $16 \%$ & $4 \%$ \\
\hline 5 & $0 \%$ & $0 \%$ & $12 \%$ & $48 \%$ & $40 \%$ \\
\hline
\end{tabular}

Table 5. Fifth Paragraph: Student Societies

\begin{tabular}{|c|c|c|c|c|c|}
\hline & $\begin{array}{c}\text { Strongly } \\
\text { agree }\end{array}$ & Agree & Neutral & disagree & $\begin{array}{c}\text { Totally } \\
\text { disagree }\end{array}$ \\
\hline 1 & $28 \%$ & $26 \%$ & $8 \%$ & $30 \%$ & $8 \%$ \\
\hline 2 & $48 \%$ & $24 \%$ & $4 \%$ & $18 \%$ & $6 \%$ \\
\hline 3 & $42 \%$ & $26 \%$ & $14 \%$ & $12 \%$ & $6 \%$ \\
\hline 4 & $24 \%$ & $18 \%$ & $12 \%$ & $36 \%$ & $10 \%$ \\
\hline 5 & $18 \%$ & $26 \%$ & $8 \%$ & $42 \%$ & $6 \%$ \\
\hline
\end{tabular}

Table 6. Sixth Paragraph: Student Training Courses

\begin{tabular}{|c|c|c|c|c|c|}
\hline & $\begin{array}{c}\text { Strongly } \\
\text { agree }\end{array}$ & Agree & Neutral & disagree & $\begin{array}{c}\text { Totally } \\
\text { disagree }\end{array}$ \\
\hline 1 & $24 \%$ & $12 \%$ & $8 \%$ & $38 \%$ & $18 \%$ \\
\hline 2 & $44 \%$ & $28 \%$ & $10 \%$ & $14 \%$ & $4 \%$ \\
\hline 3 & $18 \%$ & $12 \%$ & $16 \%$ & $40 \%$ & $16 \%$ \\
\hline 4 & $20 \%$ & $12 \%$ & $8 \%$ & $38 \%$ & $12 \%$ \\
\hline 5 & $24 \%$ & $22 \%$ & $8 \%$ & $30 \%$ & $16 \%$ \\
\hline
\end{tabular}


Table 7. Seventh Paragraph: Evaluating Staff Members

\begin{tabular}{|c|c|c|c|c|c|}
\hline & $\begin{array}{c}\text { Strongly } \\
\text { agree }\end{array}$ & Agree & Neutral & disagree & $\begin{array}{c}\text { Totally } \\
\text { disagree }\end{array}$ \\
\hline 1 & $48 \%$ & $28 \%$ & $10 \%$ & $6 \%$ & $8 \%$ \\
\hline 2 & $56 \%$ & $18 \%$ & $12 \%$ & $10 \%$ & $4 \%$ \\
\hline 3 & $72 \%$ & $14 \%$ & $6 \%$ & $6 \%$ & $2 \%$ \\
\hline 4 & $22 \%$ & $12 \%$ & $8 \%$ & $44 \%$ & $14 \%$ \\
\hline 5 & $62 \%$ & $20 \%$ & $12 \%$ & $2 \%$ & $4 \%$ \\
\hline
\end{tabular}

Table 8. Eighth Paragraph: Academic Committees

\begin{tabular}{|c|c|c|c|c|c|}
\hline & $\begin{array}{c}\text { Strongly } \\
\text { agree }\end{array}$ & Agree & Neutral & disagree & $\begin{array}{c}\text { Totally } \\
\text { disagree }\end{array}$ \\
\hline 1 & $52 \%$ & $18 \%$ & $16 \%$ & $8 \%$ & $6 \%$ \\
\hline 2 & $58 \%$ & $16 \%$ & $10 \%$ & $12 \%$ & $4 \%$ \\
\hline 3 & $44 \%$ & $24 \%$ & $18 \%$ & $6 \%$ & $8 \%$ \\
\hline 4 & $24 \%$ & $18 \%$ & $12 \%$ & $28 \%$ & $18 \%$ \\
\hline 5 & $36 \%$ & $28 \%$ & $14 \%$ & $18 \%$ & $4 \%$ \\
\hline
\end{tabular}

\section{Results and Recommendations}

This paper presents indications between the standards of the Instructional Performances in Higher-Education Institutions and the requirements for quality. A questionnaire is designed, and distributed for 75 faculty members, and just 50 questionnaires was right to evaluate the study. There are many advantages as well as many disadvantages is obtained from this study based on the requirements of quality. The study indicates that the accepted student process is developed based on equality process, and their level is convenient with their colleges, most of the faculty members experience is compatible with their departments, the number of laboratories and facilities requested for the educational process are available for the whole colleges, the evaluation of the faculty members is developed regularly, and the scientific committees are sufficient to develop all the university requests. Also, the disadvantages can be considered as the number of student is more than the ability of the college, the class, lectures hall is not sufficient, the faculty members are less than the university needed. The study recommends the following points:

1. Increase the number of the faculty member in order to equate the standards in this matter.

2. Establishing new building to save enough number of lecture halls sufficient for the student.

3. Establishing enough number of computer labs for each department for the student.

4. Developing the skills of both faculty members and student by establishing a training programme.

5. The evaluation of the faculty members should be developed regularly and considering not only the teaching process but also, researches, and activities.

6. The community service department should be more active to communicate with the environment to determine the needed of the training programmes.

The obtained points are concluded and focused to determine the defect and treatment as sensitive points and can be applied easily to improve the process.

\section{Appendix I: The Designed Questionnaire for Development the Study}

Name (Optional) Department

\begin{tabular}{|l|c|}
\hline \multicolumn{2}{|c|}{ Please put a tick in front of the item that applies to you. First: Basic Data } \\
\hline Student ( ) & Staff Member - Close Specialization ( ) : \\
\hline
\end{tabular}

\begin{tabular}{|c|c|c|c|c|c|c|}
\hline \multicolumn{2}{|r|}{$\begin{array}{l}\text { First: Selecting University Students } \\
\text { * Please tick the appropriate box of the extent of your agreement to these justifications. }\end{array}$} & $\begin{array}{l}\text { Strongly } \\
\text { agree }\end{array}$ & agree & Neutral & disagree & $\begin{array}{r}\text { Totally } \\
\text { disagree }\end{array}$ \\
\hline 1 & $\begin{array}{l}\text { Student admission is conducted in conformity with a certain criterion that is quite } \\
\text { neutral. }\end{array}$ & & & & & \\
\hline 2 & Student admission is done coping with real requirements of the community. & & & & & \\
\hline 3 & Number of students admitted is in line with human as well as material resources. & & & & & \\
\hline 4 & $\begin{array}{l}\text { Admission is done in faculties of specific studies according to ability tests set by } \\
\text { such faculties. }\end{array}$ & & & & & \\
\hline 5 & Student levels are in conformity with the faculties they study in. & & & & & \\
\hline
\end{tabular}

\begin{tabular}{|c|c|c|c|c|c|c|}
\hline \multicolumn{2}{|r|}{$\begin{array}{l}\text { Second, Staff Members } \\
\text { * Please tick the appropriate box of the extent of your agreement to these justifications. }\end{array}$} & $\begin{array}{c}\text { Strongly } \\
\text { agree }\end{array}$ & agree & Neutral & disagree & $\begin{array}{l}\text { Totally } \\
\text { disagree }\end{array}$ \\
\hline 1 & The university selects staff members according to international standards. & & & & & \\
\hline 2 & Staff members are prolific as for academic outcomes as well as teaching skills. & & & & & \\
\hline 3 & The university attempts to attract highly qualified staff members. & & & & & \\
\hline 4 & Staff members are appointed neutrally according to their close specializations. & & & & & \\
\hline 5 & Staff members have broad academic as well as research experience. & & & & & \\
\hline
\end{tabular}




\begin{tabular}{|c|c|c|c|c|c|c|}
\hline \multicolumn{2}{|r|}{$\begin{array}{l}\text { Third: University Infrastructure } \\
\text { * Please tick the appropriate box of the extent of your agreement to these justifications. }\end{array}$} & \multirow[t]{2}{*}{$\begin{array}{c}\begin{array}{c}\text { Strongly } \\
\text { agree }\end{array} \\
\end{array}$} & \multirow[t]{2}{*}{ agree } & \multirow[t]{2}{*}{ Neutral } & \multirow[t]{2}{*}{ disagree } & \multirow[t]{2}{*}{$\begin{array}{r}\text { Totally } \\
\text { disagree }\end{array}$} \\
\hline 1 & $\begin{array}{l}\text { There are an ample number of lecture halls as well as staff member offices all over } \\
\text { faculties of the university. }\end{array}$ & & & & & \\
\hline 2 & There are labs all over faculties of the university according to specialization. & & & & & \\
\hline 3 & $\begin{array}{l}\text { Labs can suffice the number of students in a way that gives the students the } \\
\text { opportunity to feasibly render the empirical section of the course. }\end{array}$ & & & & & \\
\hline 4 & $\begin{array}{c}\text { Computer labs are available in all departments, and are being used by the students } \\
\text { in respect. }\end{array}$ & & & & & \\
\hline 5 & $\begin{array}{l}\begin{array}{l}\text { Staff member offices are well qualified with computer sets as well as internet } \\
\text { connections. }\end{array} \\
\end{array}$ & & & & & \\
\hline & $\begin{array}{l}\text { Fourth: Library and Textbooks } \\
* \text { Please tick the appropriate box of the extent of your agreement to these } \\
\text { justifications. }\end{array}$ & $\begin{array}{l}\text { Strongly } \\
\text { agree }\end{array}$ & agree & Neutral & disagree & $\begin{array}{l}\text { Totally } \\
\text { disagree }\end{array}$ \\
\hline 1 & $\begin{array}{l}\text { The library encompasses all references; English and Arabic, which students as } \\
\text { well as staff members need. }\end{array}$ & & & & & \\
\hline 2 & $\begin{array}{l}\text { The total number of references is quite sufficient as for student as well as staff } \\
\text { member needs. }\end{array}$ & & & & & \\
\hline 3 & $\begin{array}{l}\text { All required references are already there in the library. They encompass all } \\
\text { academic disciplines. }\end{array}$ & & & & & \\
\hline 4 & $\begin{array}{l}\text { Students as well as staff members are allowed to borrow a number of books that } \\
\text { give coverage to all courses. }\end{array}$ & & & & & \\
\hline 5 & $\begin{array}{l}\text { The university offers low-priced editions of the textbooks just as is the case in } \\
\text { foreign universities. }\end{array}$ & & & & & \\
\hline \multicolumn{2}{|r|}{$\begin{array}{l}\text { Fifth: Student Societies } \\
\text { * Please tick the appropriate box of the extent of your agreement to these justifications. }\end{array}$} & $\begin{array}{l}\text { Strongly } \\
\text { agree }\end{array}$ & agree & Neutral & disagree & $\begin{array}{c}\text { Totally } \\
\text { disagree }\end{array}$ \\
\hline 1 & There are enough student societies all over the university. & & & & & \\
\hline 2 & $\begin{array}{l}\text { Material as well as technical support is presented by student societies in order to } \\
\text { promote creativity. }\end{array}$ & & & & & \\
\hline 3 & $\begin{array}{l}\text { The university gives students due momentum in order to promote creativity via } \\
\text { student societies. }\end{array}$ & & & & & \\
\hline 4 & $\begin{array}{c}\text { There are separate budgets for student societies in order to encourage student } \\
\text { projects and innovations. }\end{array}$ & & & & & \\
\hline 5 & The university offers technical support for student societies. & & & & & \\
\hline \multicolumn{2}{|r|}{$\begin{array}{l}\text { Sixth: Student Training Courses } \\
\text { * Please tick the appropriate box of the extent of your agreement to these justifications. }\end{array}$} & $\begin{array}{c}\text { Strongly } \\
\text { agree }\end{array}$ & agree & Neutral & disagree & $\begin{array}{c}\text { Totally } \\
\text { disagree }\end{array}$ \\
\hline 1 & $\begin{array}{l}\text { The university offers various training courses for the students during their study } \\
\text { in the university. }\end{array}$ & & & & & \\
\hline 2 & The university bears the brunt of holding periodical courses for the students. & & & & & \\
\hline 3 & There is a certain plan for giving total coverage for student training courses. & & & & & \\
\hline 4 & Training plans go in conformity with the nature of their academic specialization. & & & & & \\
\hline 5 & The university selects training courses that are trustworthy for the students. & & & & & \\
\hline \multicolumn{2}{|r|}{$\begin{array}{l}\text { Seventh: Evaluating Staff Members } \\
\text { * Please tick the appropriate box of the extent of your agreement to these justifications. }\end{array}$} & $\begin{array}{l}\text { Strongly } \\
\text { agree }\end{array}$ & agree & Neutral & disagree & $\begin{array}{c}\text { Totally } \\
\text { disagree }\end{array}$ \\
\hline 1 & $\begin{array}{l}\text { The university evaluates staff members in a periodic manner. } \\
\end{array}$ & & & & & \\
\hline 2 & The university pinpoints staff weakness in order for them to be able to strengthen it. & & & & & \\
\hline 3 & $\begin{array}{l}\text { The university impels staff members to make use of modern technology in their } \\
\text { teaching. }\end{array}$ & & & & & \\
\hline 4 & The university appoints an external member as an evaluator of the staff. & & & & & \\
\hline 5 & The university attempts to secure a contact between students and staff. & & & & & \\
\hline \multicolumn{2}{|r|}{$\begin{array}{l}\text { Eighth: Academic Committees } \\
\text { * Please tick the appropriate box of the extent of your agreement to these justifications. }\end{array}$} & $\begin{array}{c}\text { Strongly } \\
\text { agree }\end{array}$ & agree & Neutral & disagree & $\begin{array}{c}\text { Totally } \\
\text { disagree }\end{array}$ \\
\hline 1 & The university forms a number of committees that are sufficient to cover its needs. & & & & & \\
\hline 2 & $\begin{array}{l}\text { The university sets certain criteria for the performance of the academic } \\
\text { committees. }\end{array}$ & & & & & \\
\hline 3 & $\begin{array}{l}\text { The university sets certain standards for selecting members of the academic } \\
\text { committees. }\end{array}$ & & & & & \\
\hline 4 & $\begin{array}{l}\text { Academic committees encompass all academic disciplines in a way that } \\
\text { encompasses all subjects. }\end{array}$ & & & & & \\
\hline 5 & The university evaluates the committees by the end of each academic year. & & & & & \\
\hline
\end{tabular}




\section{REFERENCES}

[1] Barnett, R.(1992) "Improving Higher Education: Total Quality Care", Buckingham: SRHE\&OU.

[2] Barrow, R.(1991)"The Education Intelligence. Quoted in Barnett(1992).

[3] National Assessment and Accreditation Council, Bangalore, India, and Commonwealth of Learning, Vancouver, Canada, "Quality Assurance in Higher Education, An Introduction", June 2006.

[4] Blackmur, D. (2004). Issues in Higher Education Quality Assurance. Australian, Journal of Public Administration, 63 (2), 105-116.

[5] Lotana, J. \&Lavan, H. (1993). "Implementation of an Employee Involvement Programme in a Small Emerging High-Technology Firm", Journal of Organizational Change Management, Vol.6, No.4, pp.17-29.

[6] Buter, D. (1995-1996) Comprehensive Survey on How Companies Improve performance through Quality Efforts: Common Features Contributing to Improved Performance: http//www. Dbainc.com/ dba2/library/survey/section.

[7] Lotana, J. \&Lavan, H. (1993). "Implementation of an Employee Involvement Programme in a Small Emerging High-Technology Firm", Journal of Organizational Change Management, Vol.6, No.4, pp.17-29.

[8] Weeb, P. \& Bryant, H. (1993). "The Challenge of Kaizen
Technology of American Business Competition", Journal of Organizational Change Management, Vol. 6, No.4, pp. 9-16.

[9] Lewis, Ralph G. \& Smith, Doglas H. (1994) "Totality in higher Education”, Lucie Press, Delray Beach. Florida. Pp. 17-19.

[10] K. A. Al-Sarairah, and L. Al-Assaf, "Total Quality Management in the Higher Education Institutions Among Theory and Application" Arab Journal For Quality Assurance in Higher Education, Vol. 1, 2008, pp. 1-46.

[11] "Developing an African Higher Education Quality Rating System" Meeting of the Bureau of the Conference of Ministers Of Education of the African Union (COMEDAF II+) 29-31 May 2007, ADDIS ABABA, Ethiopia.

[12] Holmes, T. J. (1996). Total Quality Management in Higher Education: Implementation Within The Virginia Community College System. Degree of Doctor (Unpublished) George Mason University, U.S.A.

[13] Lazăr VLĂSCEANU, Laura GRÜNBERG, and Dan PÂRLEA "Quality Assurance and Accreditation: A Glossary of Basic Terms and Definitions" UNESCO - CEPES 2007.

[14] Code of Practice for the Assurance of Academic Quality and Standards in Higher Education. www.qaa.ac.uk/academicinfrastructure/codeOfPractice/defa ult.asp.

[15] EUROPEAN ASSOCIATION FOR QUALITY ASSURANCE IN HIGHER EDUCATION. Standards and Guidelines for Quality Assurance in the European Higher Education Area. Helsinki, 2005. 